\title{
SOSIALISASI PEMBERDAYAAN KADER POSYANDU DI PUSKESMAS TANJUNG MORAWA
}

\author{
Marice Simarmata ${ }^{1} *$, Ika Nur Saputri ${ }^{1}$, Raisha Octavariny ${ }^{1}$, Delita $\mathrm{Br}$ \\ Panjaitan $^{1}$, Irmayani ${ }^{1}$, Irma Nurianti ${ }^{1}$ \\ ${ }^{1}$ Program Studi Kesehatan Masyarakat Program Magister, \\ Institut Kesehatan Medistra Lubuk Pakam \\ JIn. Sudirman No.38 Lubuk Pakam, Kabupaten Deli Serdang, \\ Sumatera Utara - Indonesia \\ *email korespondensi author: maricesimarmata@medistra.ac.id
}

DOI $10.35451 /$ jpk.v1i1.712

\begin{abstract}
Abstrak
Stunting pada bayi dan balita merupakan suatu masalah gizi yang bersifat kronis yang membutuhkan penanganan secara komprehensif dan melibatkan berbagai lintas sektor. Tahun 2018 ditetapkan sebagai upaya penerapan penurunan stunting yang merupakan fokus utama dalam pembangunan nasional melalui Rencana Aksi Nasional Gizi dan Ketahanan Pangan yang ada di Indonesia. Kabupaten Tanjang Morawa termasuk salah satu yang terdapat kasus tentang stunting. Upaya penanganan stunting dengan mengoptimalkan kondisi pada pertama 1000 hari kehidupan (HPK) dapat dilaksanakan di Posyandu. Posyandu merupakan suatu tempat untk mendapatan pelayanan dalam segala bidang termasuk pemberdayaan kesehatan bagi siapa saja. Kasus stunting sering ditemukan dalam penelitian yang menunjukkan pengetahuan dan keterampilan kader harus mampu memahami stunting dan upaya pencegahannya dalam penurunan kasus tersebut. Pelaksanaan dalam pemberdayan melibatkan pendekatan secara individu, kelompok dan masyarakat serta Setelah pelatihan kader posyandu dapat lebih memahami mengenai gizi seimbang, deteksi dini stunting dan peran penting kader posyandu menginformasikan gizi optimal pada 1000 HPK sebagai upaya pencegahan stunting serta mengidentifikasi faktor risiko penyebab stunting di wilayah kerja posyandu. Diketahui dari peningkatan hasil pengetahuan pada tes setelah pelatihan. Diharapkan peningkatan kapasitas ini dibuat sebagai pelatihan berkesinambungan bersifat periodik dan terprogram dengan baik.
\end{abstract}

Kata kunci: Kader posyandu; Pemberdayaan masyarakat; stunting; Peningkatan kapasitas;

\begin{abstract}
Stunting in infants and toddlers is a chronic nutritional problem that requires comprehensive treatment and involves various cross-sectors. The year 2018 is set as an effort to implement stunting reduction which is the main focus in national development through the National Action Plan for Nutrition and Food Security in Indonesia. Tanjang Morawa Regency is one of the cases where there are cases of stunting. Stunting handling efforts by optimizing conditions in the first 1000 days of life (HPK) can be carried out at Posyandu. Posyandu is a place to get services in all fields including health empowerment for anyone. Stunting cases are often found in research that shows the knowledge and skills of cadres must be able to understand stunting and its prevention efforts in reducing these cases. Implementation in empowerment involves individual, group and community approaches and after training posyandu cadres can better understand balanced nutrition, early detection of stunting and the important role of posyandu cadres to inform optimal nutrition in 1000 HPK as an effort to prevent stunting and identify risk factors that cause stunting in the work
\end{abstract}


Received: 04 June 2021 :: Accepted: 30 June 2021 :: Published: 30 June 2021

area Integrated Healthcare Center. It is known from the increase in knowledge results on tests after training. It is hoped that this capacity building will be made as a continuous training that is periodic and well programmed.

Keywords: Posyandu cadres; Community empowerment; stunting; Capacity building;

\section{Pendahuluan}

Kesehatan merupakan suatu hal yang sangat penting dan menjadi tolak ukur untuk dapat membantu menentukan kualitas sumber data di berbagai Negara, sehingga sangat perlu dilakukan pelayanan kesehatan bagi setiap orang secara menyeluruh dan optimal baik itu kesehatan mental, fisik dan lain-lain. Stunting merupakan masalah kurang gizi kronis yang disebabkan oleh banyak faktor terutama asupan gizi yang kurang terumata pada 1000 hari pertama kelahiran dan biasanya kejadian ini sering dialami oleh anak-anak. Indonesia sendiri angka stunting cukup tinggi sekitar $37 \%$ atau setara dengan 9 juta anak indonesia. (Direktorat Promosi Kesehatan dan Pemberdayaan Masyarakat, 2018).

Sekitar 37\% (9 Juta) anak Indonesia mengalami stunting, hal ini terjadi di seluruh wilayah dan lintas kelompok pendapatan. Masalah stunting merupakan masalah besar bagi Indonesia, karena pertumbuhan yang terganggu pada anak stunting bukan hanya pertumbuhan fisiknya saja tapi juga pertumbuhan otaknya. Stunting memiliki dampak negaif bagi pertumbuhan dan perkembang anak seperti penurunan kecerdasan, rentan terhadap penyakit dan gampang lelah, dengan demikian kondisi ini akan menghasilkan generasi yang kurang aktif, menghambat sistem yang berjalan serta memperburuk keadaan yang lain. Penanganan stunting merupakan prioritas pembangunan nasional melalui Rencana Aksi Nasional Gizi dan Ketahanan Pangan sehingga pada tahun 2018 diluncurkan gerakan nasional pencegahan stunting (Biro Komunikasi dan Pelayanan Masyarakat, 2018).

Pemerintah menetapkan 160 kabupaten/kota seluruh Indonesia yang menjadi daerah prioritas penanganan stunting, Kabupaten Sumedang termasuk salah satu daerah prio-ritas tersebut (100 Kabupaten/ Kota Prioritas untuk Intervensi Anak Kerdil (Stunting), 2017).

Pemanfaatan Posyandu dalam mengatasi permasalahan stunting disesuaikan dengan visi yang ada yakni memberikan dan membuat derajat kesehatan yang optimal, sehat dan berkarakter serta mampu hidup mandiri dan mampu melakukan pemberdayaan kesehatan masyarkat yang ada di sekitanya. (Kementerian Kesehatan RI, 2012)

Posyandu adalah upaya yang akan dilakukan dalam bidang Kesehatan yang bersumberdaya Masyarakat (UKBM) yang dilaksanakan oleh dan dibuat, secara bersma-sama untuk melakukan suatu pemberdayaan guna meningkatkan kesehatan yang optimal serta terhindar dari gelaja stunting khsusnya pada balita. Masyarakat sasaran posyandu sesuai dengan target dari intervensi gizi spesifik untuk penanganan stunting. Posyandu merupakan tempat bagi ibu hamil, menyusui, bayi dan balita mendapatkan pelayanan yaitu mencakup kesehatan ibu serta bayi yang berupa pemantauan pertumbuhan dan perkembangan, pemberian kapsul vitamin A, imuni-sasi, pencegahan dan penanggulangan diare, konseling gizi sesuai masalahnya dan keluarga berencana. Kader posyandu merupakan penggerak utama yang dilakukan oleh seluruh kegiatan yang dilaksanakan di posyandu terdekat. Keberadaan kader sangat penting di harapkan ketika pelayanan kesehatan yang diberikan kepada masyarkat sehingga capain-capain yang dimaksud dapat tercapai. Seiap kader yang ikut berperan harus memiliki sifat yang mempu menopang dan aktif dalam memberikan pelayanan kepada siapapun itu karena ini akan menjadi dasar dalam menentuan kebijakan bagi 
Received: 04 June 2021 :: Accepted: 30 June 2021 :: Published: 30 June 2021

para calon ibu dan bayi, sehingga mampu melakukan kegiatan yang di rencanakan dalam setiap program posyandu tersebut.

Permasalahan posyandu sering ditemukan adalah ketidak mampuan kadaer dalam memberikan pemahaman baik dalam segi teknik. tindakan maupun pengetahuan kepada masyarkat khsusunya ibu ketika mereka mengajukan pertnyaan yang diberikan, sehingga sangat perlu sekali diberikan sosialisasi kepada setiap kader tentang pemahaman gizi yang seibmang itu seperti apa, sehingga tidak ditemukan lagi bayi atau balita mengalami stunting (Pusat Promosi Kesehatan, 2012)

Tugas kader yang terkait dengan gizi dan kesehatan antara lain melakukan pendataan balita, melakukan pengukuran berat badan, mengisi formulir kartu sehat dan melkaukan kunjungan-kunjungan kerumah-rumah ibu yang memiliki bayi, selain itu juga melakukan pendataan tentang kesedian obat seperti vitamin yang dibutuhan ibu dan anak. Setelah dilakukan hal tersebut selanjutnya kader akan melaporkan kegiatan yang telah dilakukan dalam buku catatan sehingga mempermuda pencarian akan laporan kegiatan. Penentuan status gizi ditetapkan berdasarkan hasil yang dilakuka oleh tenaga kesehatan yang ada di posyandu seperti pengukuran timbang badan, tingi badan dan kesehatan lainnya yang di anggap memiliki pengaruh terhadap status kesehatan. Direktorat Bina Gizi, 2011).

Berdasarkan penelitian Astuti, 2018 di desa tersebut diketahui bahwa 51,1\% kader tidak mendapatkan informasi tentang stunting dan sebanyak 48,8\% kader tidak memberikan penyuluhan kepada ibu balita di posyandu. Data tersebut menunjukkan bahwa peningkatan kapasitas kader Posyandu dalam bidang gizi penting dilakukan sebagai bagian dari upaya pencegahan stunting. Berdasarkan permasalahan tersebut maka perlu sekali dilakuan sosialisasi pemberdayaan kader posyandu di Tanjung Morawa.

\section{Metode}

pengabdian masayarakat pada kader posyandu di Tanjung Morawa dilakukan di Posyandu tanjung morawa tentang Sosialisasi Pemberdayaan Kader Posyandu di Puskesmas Tanjung Morawa. Dimana dalam tahapan pemberdayaan meliputi 1) melakukan kegiatan dalam mempelajari dan melakykan analisis situasi tentang permasalahan masyarakat tentang profil desa dan data-data yang mendukung serta kader di posyandu tersebut, 2) Melakukan pengamatan secara langsung pada pelaksanaan posyandu terutama dalam pelayanan kesehatan gizi di posyandu tanjung morawa, 3) Melakukan kerja sama dengan kader posyandu, merumuskan permasalahan apa yang terjadi dilingkungan tersebut.

Kegiatan pemberdayaan yang dilakukan kepada kader posyandu diharapkan kader posyandu mampu menemukan kasus stunting, melakukan pencatatan serta pelaporan yang sesuai dan memiliki tanggung jawab untuk meningkatkan kesehatan masyarkat khsuusnya dalam pencegahan stunting. Setelah dilakukan upaya maka kadier harus mampu melakukan tindakantindakan dalam mencegah stunting seperti mengenal ciri stunting dan cara mendeteksinya, mengetahui akibat dari stunting dan upaya pencegahannya, memahami gizi seimbang pada remaja putri, ibu hamil dan ibu anak-anak bawah dua tahun untuk mengoptimalkan masa 1000 hari pertama kehidupan, mampu melakukan pendampingan dan memberikan infomasi gizi yang tepat pada masyarakat sebagai upaya pencegahan stunting.

Kegiatan pelatihan sebaiknya menggunakan pendekatan model deduktif dimana pendekatan ini dilakukan secara umum dengan memberikan kelompok sasaran dan ciri yang sama, yaitu sama-sama kader posyandu. Kader Posyandu dianggap memiliki pengetahuan dan keterampilan yang hampir sama dalam bidang gizi. Kader posyandu yang mengikuti pelatihan ditentukan berdasarkan keaktifan dalam kegiatan posyandu sehingga diharapkan motivasi dan minat 
Received: 04 June 2021 :: Accepted: 30 June 2021 :: Published: 30 June 2021

terhadap pelatihan akan lebih baik dibanding kader yang tidak aktif (Kamil, 2010).

\section{Hasil dan Pembahasan}

Kegiatan pemberdayaan kader posyandu dilaksanakan dalam beberapa tahap yaitu berupa 1) sosialisasi program, 2) persiapan pelatihan dan 3) pelaksanaan pelatihan.

Sosialisasi program dilakukan sebagai rangkaian kegiatan kader posyandu untuk terlibat langsung dengan masyarakat dan memahami kondisi di lapangan. Kader psoyandu harus mempelajari dan melakukan analisis mengenai masalah masyarakat terkait dengan status gizi dan terlibat aktif dalam program peningkatan pengetahuan dan keterampilan penentuan status gizi dan pencegahan stunting, dimana dalam melakukan sosialisasi program dilakukan oleh Kepala Desa tanjung morawa yang bertujuan untuk mendapatkan izin kegiatan di desa tersebut. Sosialisasi ini juga dilakukan pada koordinator kader posyandu di setiap RW yang bertujuan menjelaskan tujuan kegiatan dan memastikan kader posyandu bersedia mengikuti pelatihan. Pelatihan ini disambut baik oleh kader posyandu. Koordinator Kader berhasil menghimpun 20 orang peserta pelatihan dari 2 Posyandu. Kegiatan ini mencakup penentuan jadwal pelaksanaan dan mempersiapkan berbagai kebutuhan sarana pelatihan. Jadwal pelatihan ditentukan menyesuaikan dengan jadwal posyandu, sehingga diharapkan kader dapat mengikuti kegiatan pelatihan dengan baik dan tidak mengganggu jadwal rutin pelayanan posyandu. Tim juga mempersiapkan konsep materi pelatihan. Seorang peneliti melakukan observasi lapangan untuk menilai proses pelaksanaan posyandu terutama mengenai kemampuan dan keterampilan kader terkait dengan materi yang akan diberikan dalam pelatihan. Data yang didapatkan kemudian didiskusikan bersama narasumber dalam sebuah diskusi kelompok, sebuah organisasi nirlaba yang fokus dalam pengembangan upaya promotif dan preventif dibidang kesehatan dan gizi. Didapatkan rancangan materi dan metode pelatihan yang dianggap paling sesuai dengan kondisi kader posyandu di Desa Tanjung Morawa. Penelitian dilakukan pada 20 orang kader posyandu aktif di Tanjung Morawa yang mengikuti pelatihan peningkatan kapasitas kader posyandu.

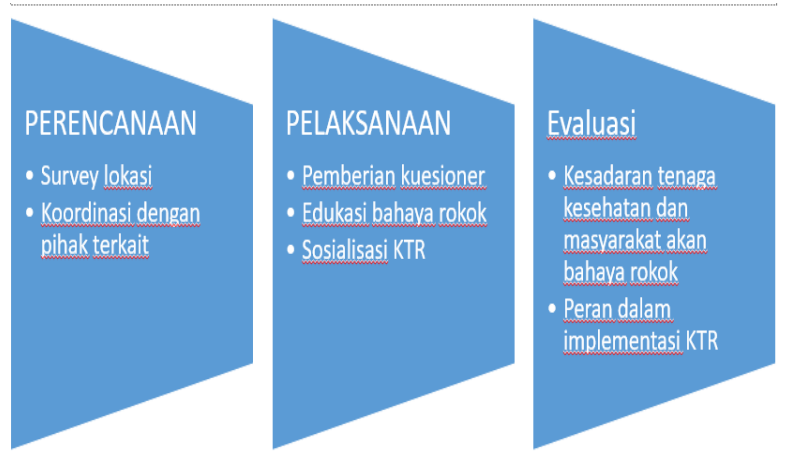

Gambar 1. Tahap Pelaksanaan kegiatan pemberdayaan kader posyandu

\section{Kesimpulan}

Berdasarkan hasil Pelatihan dalam pemberdayaan kader posyandu di tanjung morawa sebagai kader sadar gizi merupakan salah satu kegiatan dari rangkaian pengabdian pada masyarakat yang terintegrasi yang Dilaksanakan di tanjung morawa. Pelatihan dilakukan di Balai Desa tanjung morawa dihadiri oleh 20 kader posyandu terpilih dari 2 posyandu. Proses pemilihan kader peserta pelatihan ditentukan oleh ketua atau koordinator kader disetiap posyandu, dengan kriteria utama adalah kader yang aktif dalam kegiatan posyandu. Kegiatan pelatihan dilaksanakan dalam tiga tahap yaitu sosialisasi program, persiapan pelatihan dan pelaksanaan pelatihan. Pelatihan dilakukan dengan menggunakan pendekatan model deduktif, materi pelatihan dibuat sama secara umum, disusun berdasarkan data pengamatan yang dilakukan oleh tim pengabdian masyarakat kemudian didiskusikan dengan narasumber ahli. Survei untuk mendapatkan data deskriptif mengenai karakteristik kader posyandu dan pengamatan lapangan mendapatkan izin etik dari komisi etik. Kader Posyandu Desa Tanjung Morawa merasa bahwa pelatihan ini bermanfaat untuk menambah wawasan dan kapasitas 
Received: 04 June 2021 :: Accepted: 30 June 2021 :: Published: 30 June 2021

mereka mengenai gizi seimbang dan pencegahan stunting. Para peserta sangan antusias mengikuti setiap materi yang diberikan pada pelatihan. Kader peserta pelatihan mendapatkan klarifikasi berbagai pertanyaan mengenai gizi yang selama ini berkembang dengan pemahaman yang kurang tepat. Peserta juga menjadi lebih faham mengenai gizi seimbang dan peran penting kader posyandu menyampaikan informasi pada masyarakat mengenai pemberian gizi optimal pada 1000 hari pertama kehidupan (HPK) sebagai upaya pencegahan stunting. Pelatihan ini juga membantu kader untuk dapat mengidentifikasi faktor risiko apa yang menyebabkan stunting di wilayah kerja posyandu mereka. Kader posyandu di Tanjung Morawa berharap bisa mendapatkan pelatihan yang berkesinambungan yang bersifat periodik dan terprogram dengan baik sehingga peningkatan pengatahuan dan keterampilan dapat terasah terus.

\section{Ucapan Terima Kasih}

Pengabdian masyarakat ini terselenggara sebagai bagian dari Pemberdayaan Tanjung Morawa.

\section{Daftar Pustaka}

100 Kabupaten/Kota Prioritas untuk Intervensi Anak Kerdil (Stunting). (2017) (Vol. 2). Sekretariat Wakil Presiden Republik Indonesia. Diambil darihttp://www.tnp2k.go.id/imag es/uploads/downloads/Binder_Vo lume2.pdf

Astuti, S., Megawati, G., \& Samson. (2018).

Peningkatan Pengetahuan Kader Posyandu dan Ibu Balita tentang Pencegahan Stunting ( Balita Pendek ) di Desa Cipacing Kecamatan Jatinangor Kabupaten Sumedang. Dharmakarya, 3(1), 448452.DOI : http https://doi.org/10.24198/dharm akarya. v7i3.20034
Direktorat Promosi Kesehatan dan Pemberdayaan Masyarakat. (2018). Paket Informasi Stunting. Diambil dari http://promkes.kemkes.go.id/pake tinformasi-stunting. 